Conference paper (Original scientific paper)

UDC: $336.1 / .5(497)$

https://doi.org/10.18045/zbefri.2019.2.527

\title{
Effects of fiscal consolidation in Western Balkan Countries*
}

\author{
Milenko Krajišnik ${ }^{1}$, Dragan Gligorić2 ${ }^{2}$ Biljana Gojković ${ }^{3}$
}

\begin{abstract}
The global economic crisis has not spared the countries of the Western Balkans. The ensuing recession, characterized by a decline in economic activity, a decline in consumption and an increase in unemployment, went hand in hand with drops in public revenues. This in turn resulted in budget imbalances that manifested in structural budget deficits and higher public debt. Fiscal consolidation was deemed necessary across the board. In this process, certain fiscal policy elements varied among countries. The structure of public revenues and public expenditures changed. The question is whether the fiscal consolidation was successful and to what extent. Dynamic panel analysis using PMG estimator in six Western Balkan Countries for the period 2004-2016 has shown that fiscal consolidation has positive impact on economic growth in this region. So, Western Balkan Countries have to conduct responsible public finances in order to encourage economic growth.
\end{abstract}

Key words: GDP, budget deficit, fiscal consolidation

JEL: E62, H62, F41

\footnotetext{
Received: 01-06-2019; accepted: 25-12-2019

1 PhD, Associate Professor, University of Banja Luka, Faculty of Economics, Majke Jugovića 4, 7800 Banja Luka, Bosnia and Herzegovina. Scientific affiliation: international economics. Phone:0038765546019, e-mail: milenko.krajisnik@ef.unibl.org.

2 PhD, Assistant Professor, University of Banja Luka, Faculty of Economics, Majke Jugovića 4, 7800 Banja Luka, Bosnia and Herzegovina. Scientific affiliation: international economics, Phone: 0038765443355.E-mail: dragan.gligoric@ef.unibl.org

Visiting Scholar, Department of Land Economy, University of Cambridge, 19 Silver Street, Cambridge, CB39EP Cambridge, United Kingdom.E-mail:pm703@cam.ac.uk.

${ }^{3}$ MSc, Head of Economic Policy and Public Finances Department, Fiscal Council of the Republic of Srpska, Trg Republike 8/XIII Banja Luka, 0038765988335. E-mail: biljana.gojkovic@ fiskalnisavjetrs.net.
} 


\section{Introduction}

Fiscal consolidation is a process of reducing the budget deficit in order to balance public revenues and public expenditures. This process is carried out by reducing public expenditures or increasing public revenues. Very often fiscal policy measures in the consolidation process are directed both to the expenditure and to the revenue side of the budget, but one of them is mostly dominant. Fiscal consolidation often refers to reducing the share of public debt to GDP. Fiscal consolidation does not serve only its own purpose. Balanced public finances and a sustainable level of public debt are a prerequisite for economic growth, as well as a good premise for easier overcoming of economic shocks, i.e. crisis periods in the cyclical movement of the economy. This is particularly important for small open economies, at a lower level of development, as are all the countries of the Western Balkans, although they also differ from each other according to the basic macroeconomic characteristics and fiscal capacities. Regardless of these differences, all the countries of the Western Balkans ${ }^{4}$ are small open economies that cannot significantly affect world economic trends to which they are very exposed to. This was clearly seen by the impact of the global economic crisis and its consequences in those countries. The primary budget balance in all countries of the Western Balkans has worsened considerably in 2009. In all of these countries, in 2007, there was a budget surplus except Croatia and Serbia whose deficit was below $1 \%$ of GDP. The deterioration of the budget balance started in 2008, and in 2009 the deficit ranged from $2 \%$ of GDP in Macedonia, above 4\% in Bosnia and Herzegovina and Croatia to $5.9 \%$ in Montenegro. After the economic crisis, public debt also began to grow significantly in all countries. Fiscal consolidation was necessary.

The hypothesis of this paper is that fiscal consolidation conducted in the Western Balkans countries has a positive effect on economic growth.

In addition to the introduction and conclusion, this paper contains four parts. The literature review includes previous research on the impact of fiscal consolidation on the economic growth. The third part describes the methodology used in this paper while the fourth part provides an empirical analysis of the impact of fiscal consolidation on economic growth. The fifth part provides the results of research and discussion.

4 The countries of the Western Balkans usually include countries formed by the breakup of the SFR Yugoslavia, without Slovenia, with the addition of Albania. These are: Albania, Bosnia and Herzegovina, Croatia, Montenegro, North Macedonia, Serbia and Kosovo. We are dealing with the countries which are on their way to the membership in the European Union. The Republic of Croatia is a member of the European Union, but it is covered by this analysis because a part of the analyzed period refers to the years before membership, as well as because the results of the last fiscal consolidation in the Republic of Croatia are interesting from the aspect of comparative analysis with other countries of the Western Balkans. We estimate model without Kosovo due to the insufficiently long data series. Our variable of interest (cyclically- adjusted primary budget balance) is not available for Kosovo. 


\section{Literature review}

Studies which examine the effects of fiscal consolidation have been developed for different groups of countries and different periods. Some research relates to developed countries, the other for low-income countries. Also, there are research studies related to the period before the global economic crisis, but the analyses have intensified during and after the crisis that hit the world in 2008. In many countries recovery has been slow, it has lasted for several years, and in some countries for almost a decade. The results of these studies are also different. Research studies on this topic in the Western Balkan countries are not numerous, and the effects of fiscal consolidation have not been sufficiently explored.

The effects of fiscal consolidation are linked to the action of the fiscal multiplier. A fiscal multiplier is an indicator that shows the impact of changes in public spending on GDP growth. According to some authors this multiplier ranges from 0 to 0.5 . However, there are analyses that suggest that the assumptions about the height of a fiscal multiplier of 0.5 are wrong and that it can range from 0.9 to 1.7 (Blanchard, O., 2013). In conditions when central banks, due to low interest rates, cannot with further reduction stimulate economic activity and mitigate negative short-term effects of fiscal consolidation on economic activity, the fiscal multiplier could reach in some extreme cases the level of as much as 3.2 but these are rare occurrences and are characteristic for so-called "liquidity traps" (Christiano, Eichenbaum and Rebelo 2011), i.e. when the zero interest rate is not sufficiently low (Krugman, 2015). Surveys for 27 countries during the 1930s showed that in conditions of low interest rates which are close to zero, the fiscal multiplier was about 1.6 (Almunia, 2010).

The size of the fiscal multiplier varies from country to country, and depends on its economic structure, the stage of economic development, the openness of the economy, the level and structure of public expenditures and the level of indebtedness. Also, the size of the fiscal multiplier differs in the crisis period and in the period of prosperity. In the period of crisis, lower output and revenue, coupled with the poor functioning of the financial system, implies that spending may be more dependent on current than on future revenues and that investments are more dependent on current than on future profits, and both effects lead to larger multipliers (Eggertsson and Krugman, 2012).

The results of studies which examine the effects of fiscal consolidation on economic growth differ significantly. While some authors argue that reducing public spending, with an aim to reach fiscal consolidation, leads to a reduction in economic activity and negative rates of economic growth in the short term, with potential expansion in the long run (IMF, 2010) others again point to the positive effect of consolidation on economic growth. Also, it is important how consolidation is being conducted. Fiscal adjustments based on a reduction in spending are much more effective than 
those based on tax increases (Alesina and Ardagna, 2012). This is shown by fiscal consolidation studies for all OECD countries. Research studies carried out for all OECD countries in the period 1960-1994. show that there are many more years in which government spending cuts are accompanied by economic expansion rather than a recession. Later research studies confirm the results above. Research for the 16 OECD countries related to the macroeconomic effects of fiscal consolidation on the basis of reduced public spending, reduction in transfers and tax increases show that reductions in government spending and reduction in transfers are much less harmful than tax increases, despite the fact that non-distorting transfers are not classified as consumption. The effects of wealth on aggregate demand are mitigated by the impact of a sustained reduction in consumption. Static disorders caused by constant tax increases cause greater shifts in aggregate offer under the unfavorable prices (Alesina, A. et al., 2017).

Fiscal consolidations based on expenditure side of the budget are more effective than those which rely on the back side (Maroto and Mulas Granados, 2007). Consolidations carried out by an increase in income can be successful if the initial share of tax revenues in GDP is relatively low and if the increase occurs gradually. Measures aimed at limiting long-term consumption send a signal to financial markets about the sustainability of public spending (Cottarelli and Vinals, 2009).

The results of the research are also different when it comes to the economic conditions for conducting the consolidation. Some authors conclude that fiscal adjustments are more successful if they are carried out during or immediately after the recession period (Drazen and Grilli, 1993). However, a significant number of studies suggest that the right time for consolidation is the expansion time. Blanchard points out similar conclusions, arguing that fiscal expansion must play a key role in maintaining domestic demand (Blanchard, 2008). Evidence in empirical works show that there is no single multiplier for all periods of time and all countries. They can be higher or lower during the period of time and in different economies. In some cases, the effects of trust can partially compensate for the direct effects. As economies recover, and economies emerge from the liquidity trap, multipliers are likely to return to their precrisis levels. However, when considering fiscal consolidation, it seems safe to assume that fiscal multipliers will be higher during the crisis than before the crisis.

To make a decision about the application of fiscal policy instruments, there is much more that needs to be done than just estimating the size of short-term fiscal multipliers. The results that indicate the negative effect of fiscal consolidation on economic growth in particular do not mean that fiscal consolidation is undesirable. The shortterm effects of fiscal policy on economic activity are just one of the many factors that must be taken into account in determining the appropriate fiscal consolidation pace for each country (Blanchard and Leigh, 2013). Krugman points out that expansive fiscal policy is acceptable in countries facing long-term recession and low interest rates when the efficiency of monetary policy is low (Krugman, 2005). 
An analysis carried out on the sample of new EU member states reveals that expansionary fiscal shocks have a positive but relatively low impact on output. The fiscal multiplier is estimated at 1.2 in the year of shock and in the next year, while in the period after multipliers are lower, with fiscal multipliers higher in countries with low public debt and lower trade openness (Kabashi 2017).

Research studies show that the size of a fiscal multiplier depends on the country, its business cycle, the time period, but also on specific circumstances including monetary and foreign exchange regimes, degree of integration and level of openness, as well as the methodology used for their assessment. In addition, the current effects and cumulative effects of fiscal shocks may vary. Multipliers can even be negative - a phenomenon called "contraction of fiscal expansions" (Estevao, M. Samake, I. 2013). Also, fiscal institutions and fiscal rules can be helpful in increasing credibility. In the long run, better institutional frameworks can help ensure that fiscal policy stays on the right path. The analysis of the short-term effects of fiscal consolidation on economic activity in the 14 countries of Latin America and the Caribbean suggests that fiscal consolidation has a contraction effect on GDP, in line with the 0.9 multiplier (Carrière-Swallow, Y., David, AC, Leigh, (2018).

Evidence that expansive fiscal policy fosters economic growth and that reducing public spending and increasing taxes as a basis for fiscal consolidation have a negative effect are numerous. However, there are studies that indicate the possible expansive effect of fiscal consolidation. Under certain conditions, fiscal consolidation achieved through a sustained reduction in public spending increases private consumption. Reducing public expenditures which is perceived as permanent, will cause the effect of wealth. Given the reduced expenditures, market actors expect that taxes in the future will be lower, which increases the wealth of the private sector (Alesina and Perotti, 1997). The success of fiscal adjustment depends on the size and growth of public debt before consolidation. The greater the increase in public debt in the preconsolidation period the greater the probability of success of fiscal adjustment will be (Alesina and Ardagna, 1998). On the other hand, fiscal consolidation can affect the reduction of the risk premium and hence the interest rates when borrowing abroad.

Reducing the budget deficit can contribute to the reduction of the interest rate and thus stimulate components of aggregate demand that are sensitive to the change in interest rates, especially investments.

Research studies which show that fiscal consolidations had a positive impact on economic growth relate to fiscal consolidation in Denmark from 1983-86, Finland 1992-98, Sweden 1993-98. and Ireland 2008-12. (Giavazzi and Pagano, 1990; Alesina, 2010; Perotti, 2011).

There are also studies in which the results are divided and do not provide clear evidence of the long-term effect of fiscal consolidation on economic growth. The analysis of fiscal consolidation in Austria (1996), Belgium (1992), Portugal 
(1983), Spain (1994), Sweden (1984) and Great Britain (1994) shows different results. Three case studies point to rather positive effects (case studies in Portugal, Spain and the United Kingdom), while two case studies indicate a negative impact of consolidation on economic growth factors (case studies in Austria and Belgium). The result of a case study in Sweden does not provide reliable evidence of impact. Furthermore, there is no clear impact with regard to the type of fiscal consolidation, i.e. whether consolidation is primarily based on a reduction in expenditure, primarily based on an increase in revenue and equally split revenues and expenditures. The analysis points to positive and negative effects primarily in consolidation based on reducing the consumption and equally shared consolidation.

There has been limited research on Fiscal consolidation in the Western Balkan countries and the performance of fiscal multipliers. In the Western Balkan countries, since their inception, there have been more fiscal consolidations, or rather attempts. Most of these consolidations cannot be considered successful by the above criteria. An exception is the Fiscal consolidation in Serbia conducted in 2013, which has led to a reduction in the deficit. Fiscal consolidation was based on a reduction in expenditures, but there was also a decrease in public revenues to a lesser extent, and public debt continued to grow at high rates. This is exactly what the authors of the Fiscal consolidation proposal envisioned, stating that the biggest problem with the scenario envisaged by the proposal is unsustainable public debt growth (Fiscal Council, 2012). Another exception is the Fiscal consolidation in Bosnia and Herzegovina conducted in 2011-2013. This consolidation was carried out through a reduction in expenditures and an increase in revenue to approximately the same extent, but its effects were short-lived. Albania implemented fiscal consolidation in 2010 but was unsuccessful as the cyclically adjusted primary deficit started to grow as early as next year. The Fiscal multiplier was around 1.2. North Macedonia implemented fiscal consolidation in 2010, but to no avail. In North Macedonia, the CAPB has been growing since 2011 until consolidation in 2016. Montenegro implemented Fiscal consolidation in 2012, which was successful. However, due to the significant growth of expenditures, fiscal instability has again arisen. The cyclically adjusted fiscal deficit in 2015 increased to $5.84 \%$. Significant research on fiscal consolidation and fiscal multiplier developments was conducted in the Republic of Croatia. Fiscal multipliers are particularly pronounced during the recession with values well above 1, and public spending has been an effective instrument in stimulating economic activity (Grdović Gnip, 2014). Prior to the last consolidation that is the subject of this paper, four fiscal consolidations were recorded in Croatia. The first, one-year consolidation was recorded in 2000, and despite an increase in direct and indirect tax revenues, was unsuccessful but expansive, given that the GDP growth over the two-year period was significantly higher than the growth rate in the consolidation year. The only successful and expansive one-year consolidation was recorded in 2005. Then there was a reduction in expenditures on all grounds except salaries. The decline in revenue that occurred in that year was much lower than the stated decrease in expenditures. The third one-year 
consolidation is for 2010. Expenditures were reduced then, but the economic crisis also led to a decrease in direct and indirect tax revenues. Consolidation was therefore unsuccessful and followed by contraction of economic activity. The fourth multi-year consolidation in which revenue growth and expenditure reductions occurred in 20122013. years. This fiscal consolidation has further reduced the previous GDP decline, and as a result we cannot rate it as expansionary. (Burnac, P., 2017).

Analyses show that fiscal consolidation can have different effects on economic growth. Previous analyses show that fiscal consolidation can have different effects on economic growth, depending on the country's specific characteristics, which consolidation instruments are used and under what circumstances fiscal consolidation is being implemented.

\section{Methodology}

In order to explore the impact of fiscal consolidation on economic growth we first employ descriptive analysis and then we use panel data analysis.

In descriptive analysis we describe and evaluate the criteria for the period of consolidation, performance and expansion. When determining the consolidation period, it should be noted that consolidations can be one-year, or so-called cold showers and long-term or gradual consolidation. The consolidation period was determined according to the definition given by Alesina and Ardagan (1998), later modified by Mirdala (2013) for post-transition countries. The period of fiscal consolidation represents the year in which the cyclically-adjusted primary budget balance has improved by a minimum of $1.5 \%$ of GDP or a period of three consecutive years in which the cyclically-adjusted primary budget balance has not deteriorated by more than $0.5 \%$ of GDP.

According to the effects that fiscal consolidation has on the budget balance and public debt, it can be successful or unsuccessful. If fiscal consolidation has a positive impact on GDP growth, it is considered to be expansive.

The successful fiscal consolidation is one that ensures that:

a) in the three-year period after consolidation, the cyclically adjusted primary deficit on average decreases by a minimum of $2 \%$ below its value in the year of consolidation; or

b) if, three years after the consolidation, the ratio of public debt and GDP is at least $5 \%$ lower than the ratio in the year of consolidation.

Fiscal consolidation is expansive if the average growth rate of GDP in the consolidation period and two years after that period is higher than the average growth rate at the beginning of the fiscal consolidation period (Alesina and Ardagana, 1998. And Mirdala, 2013). 
In the econometric analysis we use Panel data analysis. Panel data analysis is the most appropriate for this research because it allows the inclusion of data for $\mathrm{N}$ cross-sections (countries, households, firms and etc.) during $\mathrm{T}$ time periods (months, quarters, years). Because of the possibility of including more countries in the analysis, with the possibility of respect for the specificity of the time series of each country, this analysis has gained great popularity. Basic classification panel model is static and dynamic models. Dynamic panel models, as opposed to static, are characterized by the presence of a lagged dependent among the repressors (Asteriou and Hall, 2016). A number of methods have been developed within two groups of panels. Which method is adequate for the analysis depends on the length of the time series and the number of countries subject to the analysis, their relationships, as well as from the results of unit root test. In this paper we will apply the pooled mean group (PMG) estimator which uses the panel extension of the single equation autoregressive distributed lag (ARDL) model. PMG-ARDL estimator was proposed by Pesaran (1997) and Pesaran and Shin (1999). It includes lagged dependent variable in the model and can also include lag for the independent variables if tests showed it is desirable. Models provides an effective estimation of both long and short-term effects on the basis of panel data series that include a relatively large number of observation units and time instances, provided that the analyzed variables are of the same or different level of integration, but lower than I(2). The form of the dynamic ARDL (p, q) model was defined by Paseran and Shin Paseran and Shin (1990):

$$
y_{i t}=\sum_{j=1}^{p} \lambda_{i j} y_{i, t-j}+\sum_{j=0}^{q} \delta_{i j} x_{i, t-j}+\mu_{i}+\varepsilon_{i j}
$$

Where $i$ represents the number of observation units $\mathrm{i}=1,2, \ldots ., \mathrm{N} ; \mathrm{t}$ represents the number of time instances $t=1,2, \ldots, \mathrm{T} ; \mathrm{x}_{\mathrm{it}}$ is vector of independent variables of dimension $\mathrm{k} \times 1 ; \lambda_{\mathrm{ij}}$ is coefficient of lagged dependent variable; $\mu_{\mathrm{i}}$ is parameter that determines the specific effects of the group or observation unit.

\section{Empirical data and analysis}

\subsection{Fiscal consolidation in Western Balkan Countries}

This analysis deals with fiscal consolidations that were carried out in the countries of the Western Balkans between 2014 and 2016, when the consolidation periods were completed, or they were annual as those which were carried out in $\mathrm{B} \& \mathrm{H}$, Croatia and Serbia in 2015.

The following table gives an overview of the macroeconomic and fiscal variables in the countries of the Western Balkans, the year before and in the year of fiscal consolidation. 


\begin{tabular}{|c|c|c|c|c|c|c|}
\hline 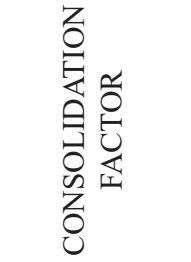 & 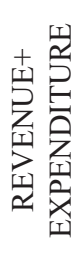 & 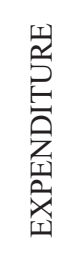 & 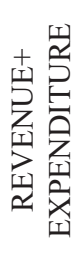 & 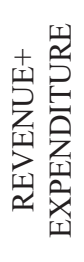 & 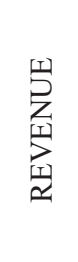 & 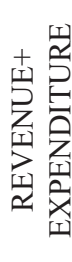 \\
\hline 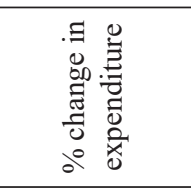 & $\begin{array}{l}\stackrel{+}{r} \\
\stackrel{+}{*}\end{array}$ & $\frac{\text { I }}{\text { ! }}$ & $\begin{array}{l}\text { ơ } \\
\stackrel{+}{1}\end{array}$ & $\stackrel{m}{n}$ & $\underset{-}{\sigma}$ & $\stackrel{\Re}{\stackrel{\Upsilon}{r}}$ \\
\hline 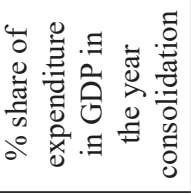 & 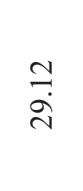 & $\begin{array}{l}\stackrel{J}{+} \\
\stackrel{\vartheta}{f}\end{array}$ & $\frac{\stackrel{丶}{\sim}}{\stackrel{\gamma}{\gamma}}$ & $\begin{array}{l}\vec{\sim} \\
\stackrel{\forall}{*}\end{array}$ & $\begin{array}{l}\text { तี } \\
\text { } \\
\text { ñ }\end{array}$ & $\begin{array}{l}\vec{b} \\
\stackrel{f}{f}\end{array}$ \\
\hline 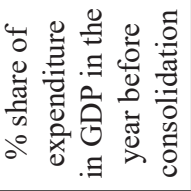 & 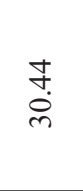 & $\begin{array}{l}\hat{N} \\
\text { ơ }\end{array}$ & $\frac{\partial}{\stackrel{\gamma}{\sigma}}$ & $\begin{array}{l}\infty \\
\infty \\
\dot{y}\end{array}$ & $\vec{i}$ & $\begin{array}{l}\bar{\infty} \\
\dot{f}\end{array}$ \\
\hline 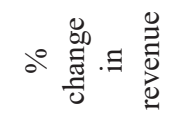 & $\vec{r}$ & $\begin{array}{l}n \\
\stackrel{n}{p} \\
?\end{array}$ & $\stackrel{I}{\ni}$ & $\begin{array}{l}\sim \\
\sim \\
n\end{array}$ & $\underset{+}{\stackrel{f}{+}}$ & $\begin{array}{l}\stackrel{\circ}{\circ} \\
\stackrel{0}{2}\end{array}$ \\
\hline 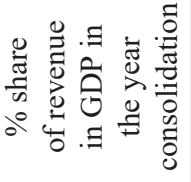 & \begin{tabular}{l}
0 \\
$\stackrel{N}{N}$ \\
\multirow{N}{*}{}
\end{tabular} & $\begin{array}{l}\tilde{\sim} \\
\ddot{\gamma}\end{array}$ & $\begin{array}{l}\stackrel{?}{f} \\
\stackrel{f}{f}\end{array}$ & $\begin{array}{l}\tilde{r} \\
\dot{\gamma}\end{array}$ & $\begin{array}{l}\stackrel{n}{\sim} \\
\infty \\
d\end{array}$ & กें \\
\hline 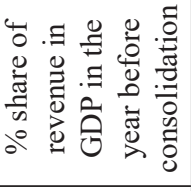 & $\begin{array}{l}\infty \\
\text { ָె} \\
\stackrel{\sim}{\sim}\end{array}$ & $\underset{\dot{\sigma}}{\dot{\nabla}}$ & $\begin{array}{l}n \\
\tilde{j} \\
\tilde{f}\end{array}$ & 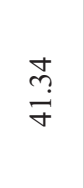 & $\frac{\sim}{\sim}$ & $\begin{array}{l}\stackrel{2}{a} \\
\infty \\
n \\
n\end{array}$ \\
\hline 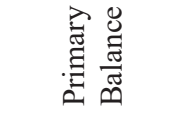 & 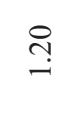 & $\widehat{\sigma o}$ & $\overline{0}$ & Oo. & 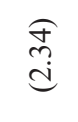 & $\ddot{0}$ \\
\hline 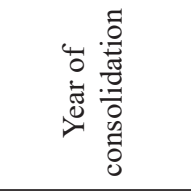 & $\stackrel{0}{\stackrel{0}{\sim}}$ & $\frac{n}{\tilde{c}}$ & $\underset{\sim}{\stackrel{ \pm}{\circ}}$ & $\stackrel{+}{\stackrel{D}{d}}$ & $\frac{n}{\stackrel{n}{d}}$ & $\stackrel{n}{\stackrel{n}{\sim}}$ \\
\hline $\begin{array}{l}\text { 蒠 } \\
\text { 己 }\end{array}$ & 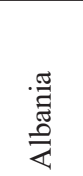 & 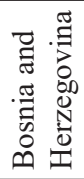 & 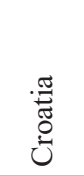 & 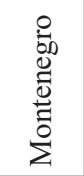 & 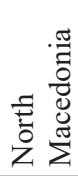 & $\begin{array}{l}\frac{\pi}{0} \\
\frac{0}{0} \\
\stackrel{0}{n}\end{array}$ \\
\hline
\end{tabular}


The analysis shows that the fiscal consolidation of the observed countries is made through an increase in revenues, a reduction in expenditures or, to some extent, one and the other. The fiscal consolidation of Albania in 2016 simultaneously influenced the increase in revenues, but also, to a great extent, the reduction of expenditures. In Albania, compared to the year before the consolidation, the share of revenue in GDP increased by $3.71 \%$, while expenditures decreased by $4.34 \%$. A similar situation in the consolidation of public finances occurred in Croatia when fiscal consolidation was significantly influenced by the increase in the share of revenue in GDP by $4.17 \%$ in relation to the year before consolidation, while the smaller effect was achieved on the side of spending cuts of $0.46 \%$. Also, in Montenegro, the increase in the share of revenues in GDP of $5.25 \%$, and also the reduction of expenditures of $3.53 \%$ led to fiscal consolidation. In Serbia, the consolidation was largely influenced by a decrease in the share of expenditures in GDP of $4.73 \%$ and a slight increase in revenues of $0.9 \%$ in relation to the year before consolidation.

Fiscal consolidation, which according to analyzes in Bosnia and Herzegovina occurred in 2015, is the result of exclusively reducing the share of expenditures in GDP by $6.12 \%$ compared to the year before consolidation. Fiscal consolidation in North Macedonia has been carried out with a $4.47 \%$ increase in revenue share in GDP. The following table shows in detail whether the implemented fiscal consolidations according to the defined criteria were successful and expansive.

The fiscal consolidation which was carried out in Albania in 2016 cannot be considered successful according to the criterion of CAPB and public debt trend. The share of public debt in GDP from $73.32 \%$ in the consolidation year was reduced to $69,92 \%$. In the three-year period after consolidation, the primary budget balance was reflected in the low surplus with the tendency of further reduction. Fiscal consolidation in Albania was expansive because the average growth rate after consolidation was higher than the average growth rate at the start of fiscal consolidation (Appendix No. 1).

Bosnia and Herzegovina has conducted a fiscal consolidation in 2015 and it can be evaluated as successful and expansive in accordance with the above criteria. In the three-year period after consolidation, the primary surplus increased by less than $2 \%$ of the share in GDP, while the public debt was lower by more than $10 \%$ in relation to the year of consolidation. At the same time, the average growth rate of GDP in the consolidation period and two years after that period was higher than the growth rate at the start of consolidation.

Fiscal consolidation carried out in Croatia in 2014 can be assessed as successful and expansive. The primary fiscal balance has been improved by more than $2 \%$, while the share of public debt in GDP has been reduced by more than $8 \%$, which is well above the targeted criterion. The growth rate of GDP was continuously higher in the consolidation period and after that period than the growth rate at the beginning of fiscal consolidation. 
Fiscal consolidation in Montenegro was carried out in 2014, but it cannot be considered as successful nor can it be judged as expansive. After the consolidation, the primary budget deficit was once again high, while public debt was above the level in the year of consolidation. The average growth rate of GDP growth was lower in the year of consolidation and two years after that period compared to the beginning of fiscal consolidation.

Fiscal consolidation in North Macedonia cannot be assessed as either successful or expansive. The primary deficit has, on average, decreased by less than $2 \%$ of the share in GDP in relation to the year of consolidation while public debt has risen. The average growth rate of GDP in the year of consolidation and two years later was lower than the average growth rate before consolidation.

Fiscal consolidation in Serbia conducted in 2015 was successful and expansive. It was successful because the primary fiscal balance has improved by more than $2 \%$ of the share in GDP, while the share of public debt in GDP was lower by $15 \%$ of the ratio in the year of consolidation. Successful fiscal consolidation was accompanied by GDP growth, and it can be valued as expansive.

\subsection{The impact of fiscal consolidation on economic growth}

This part of paper explores the impact of fiscal consolidation on economic growth in the Western Balkans countries using PMG-ARDL estimator. Data for the analysis include data for each country during the analysis period 2004-2016.

Table 2: Explanation of the variables, the method of measurement, data sources

\begin{tabular}{|l|c|c|l|l|}
\hline \multicolumn{1}{|c|}{ Variable } & \multicolumn{1}{c|}{$\begin{array}{c}\text { Type of } \\
\text { variable }\end{array}$} & $\begin{array}{c}\text { Variable } \\
\text { code in Stata }\end{array}$ & \multicolumn{1}{|c|}{$\begin{array}{c}\text { The method of } \\
\text { measurement }\end{array}$} & \multicolumn{1}{c|}{ Data source } \\
\hline $\begin{array}{l}\text { Real GDP } \\
\text { Growth rate }\end{array}$ & Dependent & gdpgr & $\begin{array}{l}\text { GDP growth at } \\
\text { constant prices }\end{array}$ & $\begin{array}{l}\text { IMF - World Economic } \\
\text { Outlook }\end{array}$ \\
\hline $\begin{array}{l}\text { Real GDP } \\
\text { Growth rate in } \\
\text { European Union }\end{array}$ & Independent & gdpeu & $\begin{array}{l}\text { GDP growth at } \\
\text { constant prices }\end{array}$ & $\begin{array}{l}\text { IMF - World Economic } \\
\text { Outlook }\end{array}$ \\
\hline $\begin{array}{l}\text { Gross fixed } \\
\text { capital } \\
\text { formation, }\end{array}$ & Independent & inv & $\begin{array}{l}\text { Gross fixed capital } \\
\text { formation in \% of GDP }\end{array}$ & $\begin{array}{l}\text { World Bank - World } \\
\text { Development Indicators }\end{array}$ \\
\hline $\begin{array}{l}\text { Inflation } \\
\text { Independent }\end{array}$ & infl & $\begin{array}{l}\text { Inflation in \%, } \\
\text { average consumer } \\
\text { prices }\end{array}$ & $\begin{array}{l}\text { IMF - World } \\
\text { Economic Outlook }\end{array}$ \\
\hline $\begin{array}{l}\text { Economic } \\
\text { Openness }\end{array}$ & Independent & trade & $\begin{array}{l}\text { Sum of export and } \\
\text { import (as \% of GDP) }\end{array}$ & $\begin{array}{l}\text { World Bank - World } \\
\text { Development Indicators }\end{array}$ \\
\hline $\begin{array}{l}\text { Ciclically- } \\
\text { adjusted primary } \\
\text { budget balance }\end{array}$ & Independent & capb & $\begin{array}{l}\text { Ciclically- adjusted } \\
\text { General government } \\
\text { primary net lending/ } \\
\text { borrowing }\end{array}$ & $\begin{array}{l}\text { IMF - Article IV } \\
\text { Consultation and authors } \\
\text { calculation }\end{array}$ \\
\hline
\end{tabular}




\begin{tabular}{|l|c|c|l|l|}
\hline \multicolumn{1}{|c|}{ Variable } & $\begin{array}{c}\text { Type of } \\
\text { variable }\end{array}$ & $\begin{array}{c}\text { Variable } \\
\text { code in Stata }\end{array}$ & \multicolumn{1}{|c|}{$\begin{array}{c}\text { The method of } \\
\text { measurement }\end{array}$} & Data source \\
\hline $\begin{array}{l}\text { Foreign direct } \\
\text { investment }\end{array}$ & Independent & fdi & $\begin{array}{l}\text { Foreign direct } \\
\text { investment in \% of } \\
\text { GDP }\end{array}$ & $\begin{array}{l}\text { World Bank - World } \\
\text { Development Indicators }\end{array}$ \\
\hline $\begin{array}{l}\text { Real effective } \\
\text { exchange rate }\end{array}$ & Independent & reer & $\begin{array}{l}\text { Real effective exchange } \\
\text { rate, Index (increase } \\
\text { means appreciation) }\end{array}$ & $\begin{array}{l}\text { Braugel datasets, } \\
\text { IMF - Article IV } \\
\text { Consultation and authors } \\
\text { calculation }\end{array}$ \\
\hline Remittances & Independent & remit & $\begin{array}{l}\text { Personal remittances, } \\
\text { received (\% of GDP) }\end{array}$ & $\begin{array}{l}\text { World Bank - World } \\
\text { Development Indicators }\end{array}$ \\
\hline
\end{tabular}

Analysis of the impact of fiscal consolidation on economic growth implies estimation regression equation, in which dependent variable is real GDP growth rate while independent variable is cyclically-adjusted primary budget balance as a percentage of GDP. In order to get a reliable estimation of impact of cyclicallyadjusted primary budget balance on economic growth, it is necessary to include a number of other control variables that could have an impact on the economic growth according to previous research. The assumption of the analysis is that the fiscal consolidation, i.e. increase of cyclically-adjusted budget balance has a positive impact on economic growth in the analyzed countries, in accordance with the theoretical assumptions and the results of most of previous research. The same assumption applies to gross fixed capital formation (investment). Larger investments mean higher economic growth, while investments have not only direct but also indirect impact (multiplier) on economic growth.

Inflation, as measured by the average annual percent of change influences the cost of the average consumer acquiring a basket of goods and services. Most of transition countries have been affected with hyperinflation period and high uncertainty which is caused by high inflation. We assume that higher inflation in Western Balkans countries means high uncertainty and smaller GDP growth, i.e. expected sign of coefficient of this variable is negative. Degree of economic openness can have both positive and negative impact on economic growth. It depends whether the countries small or large, export or import oriented and also whether in the neighbor countries economic expansion or downturn. If countries are small, import dependable and if in neighbor counties are face with economic slowdown, such is situation in the Western Balkan countries in the most of period analysis, expected impact of economic openness on the economic growth is negative. Effects of foreign direct investments can be positive, if these investments are directed to production and include technology and know-how transfers from abroad. But also their impact can be negative if investments from abroad are directed to ownership transformation without investment in new equipment and production expansion or if they overwhelmingly directed to tertiary sector which is related to import product and services from abroad. 
The real exchange rate is a product of the nominal exchange rate and the price ratio in the country and abroad. According to the methodology of calculating the real effective exchange rate index used in this research, index increase indicates appreciation. The appreciation of the real exchange rate can ultimately have both a positive and a negative effect on economic growth. If the effect of the appreciation of the exchange rate on the fall of exports and thus the fall of GDP dominates, the effect will be negative. If the positive effect of the appreciation of the exchange rate on the fall in the interest rate and the consequent growth of economic activity dominate, the effect of the appreciation of the real exchange rate on the GDP will be positive (Arratibel and Henrike, 2013). Remittances from abroad can have positive and negative impact on the economic growth, unless they cause less reediness to work and therefore larger unemployment.

In the next table, a descriptive statistic of our dependent and independent variable are shown for the observed period (2004-2016). The highest average real growth rate was recorded in Albania, while the lowest real average growth rate was in Croatia. The country with the most volatile growth rate was Serbia. The smallest average cyclically-adjusted primary budget deficit was in Bosnia and Herzegovina, while the highest average deficit was made by Croatia. Macedonia was country with the highest volatile budget balance. The standard deviation was 3.87, which is more than 1 percentage point higher that of deviation recorded in any other country.

Table 3: Descriptive statistics

\begin{tabular}{|l|c|c|c|c|c|c|c|c|}
\hline Country & $\begin{array}{c}\text { Mean } \\
\text { (gdpgr) }\end{array}$ & $\begin{array}{c}\text { Min } \\
\text { (gdpgr) }\end{array}$ & $\begin{array}{c}\text { Max } \\
\text { (gdpgr) }\end{array}$ & $\begin{array}{c}\text { Sd } \\
\text { (gdpgr) }\end{array}$ & $\begin{array}{c}\text { Mean } \\
(\mathrm{capb})\end{array}$ & $\begin{array}{c}\text { Min } \\
(\mathrm{capb})\end{array}$ & $\begin{array}{c}\text { Max } \\
(\mathrm{capb})\end{array}$ & $\begin{array}{c}\text { Sd } \\
(\mathrm{capb})\end{array}$ \\
\hline ALB & 3.83 & 1.02 & 7.50 & 2.06 & -1.10 & -4.50 & 1.20 & 1.50 \\
\hline BIH & 2.90 & -0.82 & 6.26 & 2.52 & -0.64 & -5.80 & 2.95 & 2.84 \\
\hline CRO & 1.09 & -7.29 & 5.28 & 3.56 & -1.62 & -3.75 & 2.30 & 2.04 \\
\hline MKD & 3.43 & -0.46 & 6.47 & 2.06 & -1.38 & -5.84 & 8.64 & 3.87 \\
\hline MNE & 3.10 & -5.80 & 8.60 & 3.86 & -1.15 & -3.25 & 1.32 & 1.67 \\
\hline SRB & 3.24 & -2.73 & 10.15 & 3.93 & -1.60 & -3.70 & 2.90 & 2.20 \\
\hline
\end{tabular}

Taking into account degree of correlation between observed variable is very important, due to the possibility of multicolinearity problem. Multicolinearity is a problem in regression analysis that occurs when two independent variables are highly correlated. The correlation coefficient between our independent variable is very small, which is desirable. The highest correlation is between real GDP Growth rate in European Union growth rate and cyclically- adjusted primary budget balance but it is not so high. This means that multicolinearity problem will not manifest in our model. Correlation matrix shows that regressors do not have perfect or exact linear relationship of each other. 
Table 4: Correlation matrix

\begin{tabular}{|l|r|r|r|r|r|r|r|r|}
\hline & \multicolumn{1}{|c|}{ gdpeu } & \multicolumn{1}{c|}{ inv } & \multicolumn{1}{c|}{ infl } & trade & capb & fdi & reer & remit \\
\hline gdpeu & 1 & & & & & & & \\
\hline inv & 0.017 & 1 & & & & & & \\
\hline infl & -0.1078 & 0.1834 & 1 & & & & & \\
\hline trade & 0.2261 & -0.1285 & -0.0272 & 1 & & & & \\
\hline capb & 0.4163 & -0.0841 & -0.1992 & 0.1953 & 1 & & & \\
\hline fdi & -0.0584 & 0.2486 & 0.2298 & 0.3115 & 0.0378 & 1 & & \\
\hline reer & -0.1465 & 0.1228 & 0.1594 & 0.4347 & -0.3026 & 0.0764 & 1 & \\
\hline remit & 0.0323 & 0.2918 & -0.0497 & -0.2527 & 0.045 & -0.2775 & -0.1671 & 1 \\
\hline
\end{tabular}

To determine the appropriate econometric model to analyze the impact of fiscal consolidation on economic growth, it is necessary to detect whether the series of data analyzed variables are stationary. Since the panel models are a combination of the "cross-country" analysis and time series analysis, panel models are inherent problems typical for the non-stationary time series. If we use variables which follow unit root process in the static panel, we will face with the spurious regression. Also, results of unit root test (i.e. order of integration) are indicators for choosing the appropriate model for panel analyses among plenty of available models. Testing stationarity and verification of the order of integration of the variables is performed using the unit root tests. In this paper, panel unit root tests were conducted using Im, Pesaran, and Shin test (IPS), because IPS test does not require strongly balanced data such is the case in our analysis. If variable has unit root at level, we test for unit root at 1 st difference.

Table 5: Results of the unit root test

\begin{tabular}{|l|c|c|c|}
\hline \multicolumn{1}{|c|}{ Variable } & Level & 1st difference & $\mathrm{I}(\mathrm{d})$ \\
\hline gdpgr & unit root & no unit root & $\mathrm{I}(1)$ \\
\hline gdpeu & no unit root & & $\mathrm{I}(0)$ \\
\hline inv & unit root & no unit root & $\mathrm{I}(1)$ \\
\hline infl & no unit root & & $\mathrm{I}(0)$ \\
\hline trade & unit root & no unit root & $\mathrm{I}(1)$ \\
\hline capb & unit root & no unit root & $\mathrm{I}(1)$ \\
\hline remit & unit root & no unit root & $\mathrm{I}(1)$ \\
\hline reer & unit root & no unit root & $\mathrm{I}(1)$ \\
\hline fdi & no unit root & & $\mathrm{I}(0)$ \\
\hline
\end{tabular}

Source: authors' calculations using Stata/SE 15.1 
Most of the tests of the unit root show that most of variables are stationary in the level of I(1), i.e. have unit root. but we have some variables which are integrated at zero order $\mathrm{I}(0)$. So we have combination of variables which have different level of integration, but lower than I(2). Therefore, the most appropriate econometric model for our analysis is PMG-ARDL estimator.

Prior to starting with the estimation of our model, we applied autoregressive distributed lag (ARDL) model for each country in the panel, to detect which lag is optimal for PMG-ADRL model. According to the Bayesian information criteria (BIC) we determine optimal lag for each variables for that country. At the end, we choose the most common lag for each variable to represent the lags for the model. For dependent variable (GDP growth rate), foreign direct investment, remittances, real exchange rate, and budget balance optimal lag was 1, but for other independent variable optimal lag was 0 . Also, we estimate model without Kosovo due to the insufficiently long data series. Our variable of interest (cyclically- adjusted primary budget balance) is not available for Kosovo.

Except the PMG model, we also estimate MG model in order to determine which model is more adequate according to the Hausman test. Mean Group estimator is less informative than the PMG estimator, because MG estimator estimate the mean of long and short-run coefficients across countries by the unweighted average of the individual country coefficients. Both, the long-run and short-run coefficient obtained using MG estimator are country specific, i.e. we cannot obtain coefficient which is common for each country in the panel. PMG estimator, introduced by Pesaran, Shin and Smith (1999), restricts the long-run slope coefficients to be the same across countries but allows the short-run coefficients (including the speed of adjustment) and the regression intercept to be country specific. So, long-run coefficient obtained using PMG estimator is common for all countries in the panel.

We estimate several models, including different combination of variables presented in Table 3. Models which included a lot of independent variables, do not pass specification test (Hessian has become unstable or asymmetric). Two models, which satisfied specification criteria are presented in Table 6. 
Table 6: The Long and short-run effect of fiscal consolidation on real economic growth in Western Balkan Countries

\begin{tabular}{|c|c|c|c|c|}
\hline \multirow{3}{*}{ Variables } & \multicolumn{2}{|c|}{ Model 1} & \multicolumn{2}{|c|}{ Model 2} \\
\hline & $\begin{array}{l}\text { Pooled Mean } \\
\text { Group (PMG) }\end{array}$ & $\begin{array}{c}\text { Mean Group } \\
\text { (MG) }\end{array}$ & \begin{tabular}{|l|} 
Pooled Mean \\
Group (PMG) \\
\end{tabular} & $\begin{array}{l}\text { Mean Group } \\
(\mathrm{MG})\end{array}$ \\
\hline & Coef. & Coef. & Coef. & Coef. \\
\hline \multicolumn{5}{|c|}{ Long-run Coefficients } \\
\hline $\begin{array}{l}\text { Real GDP Growth rate in EU } \\
\text { (gdpeu) }\end{array}$ & $\begin{array}{r}1.008 * * * \\
(0.130)\end{array}$ & $\begin{array}{c}1.620 * * \\
(0.666)\end{array}$ & $\begin{array}{r}0.937 * * * \\
(0.130)\end{array}$ & $\begin{array}{l}-0.033 \\
(0.588)\end{array}$ \\
\hline Investment (inv) & $\begin{array}{r}0.238 * * * \\
(0.063)\end{array}$ & $\begin{array}{r}1.798 \\
(1.566)\end{array}$ & $\begin{array}{r}0.493 * * * \\
(0.061)\end{array}$ & $\begin{array}{r}0.507 * * \\
(0.197)\end{array}$ \\
\hline Foreign direct investments (fdi) & $\begin{array}{r}-0.110 * * \\
(0.053) \\
\end{array}$ & $\begin{array}{r}0.405 \\
(0.412) \\
\end{array}$ & & \\
\hline Real effective exchange rate (reer) & & & $\begin{array}{r}-0.185^{* * *} \\
(0.050) \\
\end{array}$ & $\begin{array}{r}0.129 \\
(0.242) \\
\end{array}$ \\
\hline $\begin{array}{l}\text { Cyclically- adjusted primary } \\
\text { budget balance (capb) }\end{array}$ & $\begin{array}{r}0.599 * * * \\
(0.082) \\
\end{array}$ & $\begin{array}{l}-1.379 \\
(1.666) \\
\end{array}$ & $\begin{array}{r}0.256 * * * \\
(0.071) \\
\end{array}$ & $\begin{array}{r}0.847 * * * \\
(0.255) \\
\end{array}$ \\
\hline Error Correction Coefficients & $\begin{array}{r}-0.945 * * * \\
(0.234) \\
\end{array}$ & $\begin{array}{r}-0.974 * * * \\
(0.319) \\
\end{array}$ & $\begin{array}{r}-0.873 * * * \\
(0.208) \\
\end{array}$ & $\begin{array}{r}-1.185 * * * \\
(0.317) \\
\end{array}$ \\
\hline \multicolumn{5}{|c|}{ Short-run Coefficients } \\
\hline $\begin{array}{l}\Delta \text { Real GDP Growth rate in EU } \\
\text { (gdpeu) }\end{array}$ & $\begin{array}{l}-0.058 \\
(0.223)\end{array}$ & $\begin{array}{l}-0.096 \\
(0.240)\end{array}$ & $\begin{array}{r}0.052 \\
(0.233) \\
\end{array}$ & $\begin{array}{l}-0.008 \\
(0.234) \\
\end{array}$ \\
\hline$\Delta$ Investment (inv) & $\begin{array}{r}-0.207 \\
(0.247) \\
\end{array}$ & $\begin{array}{r}-0.120 \\
(0.186) \\
\end{array}$ & $\begin{array}{r}-0.218 \\
(0.224) \\
\end{array}$ & $\begin{array}{r}0.045 \\
(0.241) \\
\end{array}$ \\
\hline$\Delta$ Foreign direct investment (infl) & $\begin{array}{r}0.027 \\
(0.070) \\
\end{array}$ & $\begin{array}{r}0.398 \\
(0.515) \\
\end{array}$ & & \\
\hline $\begin{array}{l}\Delta \text { Real effective exchange rate } \\
\text { (reer) }\end{array}$ & & & $\begin{array}{c}0.180 * * \\
(0.076) \\
\end{array}$ & $\begin{array}{r}0.159 \\
(0.167) \\
\end{array}$ \\
\hline $\begin{array}{l}\Delta \text { Cyclically - adjusted primary } \\
\text { budget balance (capb) }\end{array}$ & $\begin{array}{c}-0.649 * \\
(0.387)\end{array}$ & $\begin{array}{l}-0.534 \\
(0.387)\end{array}$ & $\begin{array}{l}-0.120 \\
(0.169) \\
\end{array}$ & $\begin{array}{l}-0.799 * \\
(0.473) \\
\end{array}$ \\
\hline Constant & $\begin{array}{r}-1.870 * * * \\
(0.206)\end{array}$ & $\begin{array}{r}10.246 \\
(16.882)\end{array}$ & $\begin{array}{r}8.074 * * * \\
(2.069)\end{array}$ & $\begin{array}{l}-27.658 \\
(24.293)\end{array}$ \\
\hline Hausman test & chi $2=2.27$, Prob & $>\operatorname{chi} 2=0.6862$ & chi $2=0.22$, Prol & chi2 $=0.9942$ \\
\hline Log Likelihood & -79.93 & & -81.82 & \\
\hline Observations & 68 & & 68 & \\
\hline
\end{tabular}

Standard errors in parentheses

$* * * \mathrm{p}<0.01, * * \mathrm{p}<0.05, * \mathrm{p}<0.1$ 
As presented in the regression results, Hausman test shows that PMG estimator is more efficient than MG estimator. P-value of Hausman test is greater than 0.05, which implies that the homogeneity restriction is not rejected jointly for all longrun parameters. Also, according to the log likelihood criteria, model 2 is better than model 1. Therefore, we accept PMG estimation as relevant for our model and our conclusion focuses on the results obtained with the PMG estimator and model 2.

In the long run, the real growth rate of GDP is positively related to real GDP growth rate in European Union, the investment, and the cyclically-adjusted primary budget balance. These are standard results from the empirical literature, and it is reassuring that we are able to reproduce them with our methodology. The real exchange rate has a negative impact on economic growth in Western Balkan Countries in the long run, which is not surpassing. Increase in real effective exchange rates indicates real appreciation, i.e. loss of external price competitiveness, which has negative impact on economic growth. If we look at the model 2, estimation results show that real economic growth in EU for $1 \%$ led to the increase the real economic growth in Western Balkan countries for $0.94 \%$ in the long- run. Investment also has a positive impact of economic growth. The estimated coefficient is 0.49 an it is significant at $1 \%$. Real exchange rate appreciation for $1 \%$ leads to decline in economic growth for $0.19 \%$. All long run variables in our targeted model (model 2 ) are statistically significant an $1 \%$.

Our variable of special interest, the cyclically-adjusted primary budget balance, has a positive impact on economic growth of Western Balkan Countries in the long run. The coefficient is positive and statistically significant at $1 \%$ level. If share of cyclically- adjusted primary budget balance in GDP increase by $1 \%$, the real economic growth in Western Balkan Countries will grow for $0.26 \%$. This means that fiscal consolidation has a positive impact on economic growth in this region.

As explained earlier, short-run coefficients are not restricted to be the same across countries, so that we do not have a single pooled estimate for each coefficient. But we can still analyze the average short-run effect by considering the mean of the corresponding coefficients across The short-run coefficients in our estimated model is not statistically significant except real effective exchange rate which is significant at 5\% level of significance and positive. This means that in the short run, real exchange appreciation stimulates economic growth, as opposed to long run. So we can conclude that in the long run, a real exchange rate affects economic growth through trade channel (stimulate export and de-stimulate import), while in short run, appreciation of real exchange rate stimulates economic growth through a reduction in interest rates.

Error correction term (ECT) is also country specific. The existence of a long-run relationship among the variables of interest requires that, the coefficient on the error-correction term has to be negative and not lower than -2. In our model, error 
correction term is statistically significant at $1 \%$ level and negative, which means that variables in our model have long rung equilibrium. It amounts to -0.94 which means that speed of adjustment to the long run equilibrium is very high.

\section{Results and discussion}

This paper analyzes the impact of fiscal consolidation on the economic growth of the Western Balkan countries. The results of the study show that fiscal consolidation has a positive impact on economic growth in the countries observed. First part of the research deals with fiscal consolidation that took place in the Western Balkan countries between 2014 and 2016. It analyzes the performance of fiscal consolidation and expansion. The analysis shows that fiscal consolidation of the observed countries is done by increasing revenues, reducing expenditures, or to some extent, both. The analysis shows that fiscal consolidation of the observed countries is made through an increase in revenues, a reduction in expenditures or, to some extent, one and the other. The results of this part of the study show that fiscal consolidation was successful in those countries that implemented fiscal consolidation largely by reducing expenditures. The same conclusions are drawn from the results of the fiscal consolidation survey in OECD countries. It concluded that fiscal adjustments based on spending cuts are much more effective than those based on tax cuts. Measures to limit long-term spending send impulse to the financial markets on the sustainability of public spending. Also, analysis shows that fiscal consolidations are more successful under expansion than in times of crisis. Similar results are shown by the analyzes carried out on a sample of new EU Member States. These analyzes have shown that the fiscal multiplier is lower in years of prosperity than in years of crisis.

In the second part of the paper, we analyzed the impact of fiscal consolidation on economic growth, which used data for each country during the analyzed period. The dependent variable in the analysis is the real GDP growth rate, and the independent variable is a cyclically adjusted primary budget balance. We have assumed that fiscal consolidation has a positive effect on economic growth in the analyzed countries. This is consistent with the theoretical assumptions and results of most previous research. The analysis showed that the real GDP growth rate in the long run is positively correlated with the real GDP growth rate in the European Union, investment and the primary budget balance. If we analyze impact of other control variables in the model, results show that real economic growth in the EU by $1 \%$ led to an increase in real economic growth in the Western Balkan countries by $0.94 \%$ in the long run. Investment has a positive impact on economic growth. The estimated coefficient is 0.49 and is significant at $1 \%$. Also, real exchange rate appreciation for $1 \%$ leads to decline in economic growth for $0.19 \%$. This results are in line with expectations and results of previous research. 
The most important result of the research is that the cyclically-adjusted primary budget balance has positive impact on the economic growth of the Western Balkan countries in the long-term. Coefficient is statistically significant at the $1 \%$ level. Value of coefficient is 0.26 which shows that increase in share of the cyclicallyadjusted primary budget balance in GDP for $1 \%$ would increase real economic growth in the Western Balkan by $0.26 \%$. This means that fiscal consolidation has a positive impact on economic growth in this region.

The scientific contribution is that small, open, import-dependent economies with low levels of public debt can influence economic growth through fiscal stabilization. Our results are in line with previous research conducted for OECD countries and 26 European economies. Also, our results correspond to the results of the sample of the new EU Member States. To our best knowledge, this is the first study on the effects of fiscal consolidation to cover the Western Balkan countries.

This research shows that policymakers have to be persistent in pursuing fiscal consolidation, because it is an effective tool for stimulating economic growth. More efficient fiscal consolidation is the one achieved by reducing fiscal expenditures compared to consolidation achieved by fiscal revenue growth.

\section{Conclusions}

Our analysis, conducted in this research for the period 2004-2016 in six Western Balkan countries, has shown that fiscal consolidation has a positive impact in real economic growth. So the results confirm our main hypothesis.

Increase in cyclically-adjusted primary budget balance for $1 \%$ of GDP led to increase in real economic growth in Western Balkan Countries for $0.26 \%$ in the long-run. The Hausman test has given priority to Pool Mean Group compared to Mean group estimator, which mean that this characteristic is common for whole this region.

Fiscal adjustments based on a reduction in spending are much more effective than those based on tax increases. Under certain conditions, fiscal consolidation achieved through a sustained reduction in public spending increases private consumption. Reducing the budget deficit can contribute to the reduction of the interest rate and thus stimulate components of aggregate demand that are sensitive to the change in interest rates, especially investments. Previous analyses show that fiscal consolidation can have different effects on economic growth, depending on the country's specific characteristics, which consolidation instruments are used and under what circumstances fiscal consolidation is being implemented. Fiscal consolidation that has been implemented in the Western Balkan Countries was successful. The exceptions are Montenegro and Macedonia in which primary 
budget deficit has not decreased, public debt has continued to grow and economic growth was lower than the period before the consolidation.

Balanced public finances and a sustainable level of public debt are a conditions for economic growth, as well as a good premise for easier overcoming of economic shocks, i.e. crisis periods in the cyclical movement of the economy.

Limitations in the research are the lack of data for some countries and very and short time series. Future research will be focused on the impact of change in structure of public expenditure on the economic growth in the Western Balkan countries.

\section{References}

Alesina, A., Ardagna, S. (2012) "The Design of Fiscal Adjustments", NBER Working Paper, Washington, DC: National Bureau of Economic Research, Vol. 27, No. 18423, http://dx.doi.org/10.3386/w18423.

Alesina A., Ardagna, S. (1998) "Tales of Fiscal Adjustment, Economic Policy”, Digital Access to Scholarship at Harvard: Harvard Library, Vol. 13(27), pp. 489-585, http://dx.doi.org/10.1111/1468-0327.000039.

Alesina, A., Barbiero, O., Favero, C., Giavazz, F., Paradisi, M. (2017) “The Effects of Fiscal Consolidations" Theory and evidence, NBER Working Paper, Massachusetts Avenue Cambridge: National Bureau of Economic Research, No. 23385, http://dx.doi.org/10.3386/w23385.

Alesina, A., Perotti, R. (1997) "Fiscal Adjustments in OECD Countries: Composition and Macroeconomic Effects", IMF Staff Papers, No. 44, pp. 210-24, http://dx. doi.org/10.2307/3867543.

Arratibel, O., Michaelis, H. (2013) “The Impact of Monetary Policy and Exchange Rate Shocks in Poland: Evidence from a Time-Varying VAR" Discussion Papers in Economics 2013-36, https://doi.org/10.5282/ubm/epub.21088.

Asteriou, D., Hall, S.G. (2016) “Aplied Econometrics”. 3rd Edition. Palgrave MacMilan.

Blanchard, O., Leigh, D. (2013) "Growth Forecast Errors and Fiscal Multipliers", IMF Working Paper, No. WP/13/1, http://dx.doi.org/10.1257/aer.103.3.117.

Blanchard, O. (2008) “The Tasks Ahead”, IMF Working paper, No. 08/262.

Bruegel Datasets (2019) Retrieved on the date 13.12.2019 from https://bruegel.org/ publications/datasets/real-effective-exchange-rates-for-178-countries-a-newdatabase/.

Burnać, P. (2017) "Fiscal consolidation: of theoretical barriers and the case of the Republic of Croatia", Faculty of Economics Split, Croatia, file://C:/Users/ Korisnik/Downloads/Clanak_17_06.pdf. 
Cottarelli, C., Vinals, J. (2009) “A Strategy for Renormalizing Fiscal and Monetary Policies in Advances Economies", IMF Staff Position Note, Br. 09/22.

Carrière, S.Y., David, A., Leigh, D. (2018) "The Macroeconomic Effects of Fiscal Consolidation in Emerging Economies" Evidence from Latin America, IMF, Working Paper, No. WP/18/142.

Eggertsson, B., Krugman, P. (2012) "Debt, Deleveraging, and the Liquidity Trap", Quarterly Journal of Economics, pp. 1469-513, http://dx.doi.org/10.1093/qie/qis023.

Estevao, M. Samake, I (2013) "The Economic Effects of Fiscal Consolidation with Debt Feedback”, IMF Working Paper, WP/13/136, http://dx.doi.org/10.5089/ 9781484304488.001.

Giavazzi, F., Pagano, M. (1990) "Can severe fiscal contractions be expansionary? tales of two small european countries" NBER Macroeconomics Annual 5, pp. 75-122, http://dx.doi.org/10.2307/3585133.

Government of Macedonia (2019) "Economic reform programme 2019-2021", Retrieved on the date 13.12.2019 https://ec.europa.eu/neighbourhoodenlarge $\mathrm{ment} / \mathrm{sites} /$ near/files/north_macedonia_erp_2019 2021.pdf.

Government of Montenegro (2019) "Montenegro economic reform programme 2019-2021", Retrieved on the date 13.12.2019 https://ec.europa.eu/neighbour hood-enlargement/sites/near/files/montenegro_erp_2019-2021.pdf.

Grdović, Gnip, A. (2014) “The Power of Fiscal Multipliers in Croatia”, Financial Theory and Practice, Vol. 38 (2), str. 173-219, http://dx.doi.org/10.3326/fintp. 38.2.3.

Fiscal Council, Republic of Serbia (2012) "Proposal of Fiscal consolidation measures 2012-2016".

Kabashi, R. (2017) "Macroeconomic effects of fiscal policy in the European Union with particular reference to transition countries", Public Sector Economics, Vol. 41 (1), p. 3969, http://dx.doi.org/10.3326/pse.4117.

Klajs, M., Moessinger, M-D. (2016) "The Long-run Effect of Fiscal Consolidation on Economic Growth: Evidence from quantitative case studied", Valencia, Spintan, Working Paper Series, No. 6, http://dx.doi.org/10.2298/ssrn.2801590.

Krugman, P. (2005) "Is Fiscal Policy Poised for a Comeback", Oxford Review of Economic Policy, Vol. 21, No. 4, pp. 515-523, http://dx.doi.org/10.2139/ PAN1102143A.

IMF, Article IV Consultation-Press Release, "Staff Report; and Statement by the Executive Director for the Former Yugoslav Republic of Macedonia", Retrieved on the date 13.12.2019 https://www.imf.org/en/countries/mkd?selectedfilters= Article\%20IV\%20Staff\%20Reports\#whatsnew.

Lawrence, C., Eichenbaum, M.,and Rebelo, S. (2011) "When Is the Government Spending Multiplier Large?", Journal of Political Economy, Vol. 119, pp. 78121, http://dx.doi.org/10.1086/659312. 
Mirdala, R. (2013) "Lessons learned from Tax vs. Expenditures Based Fiscal Consolidation in the European Transition Economies", William Davidson Institute, Working Paper, Br. 1058.

Pesaran, M. Hashem, Yongcheol Shin, and Ron P. Smith (1997) "Pooled Estimation of Long-Run Relationships in Dynamic Heterogenous Panels", EconPapers, Retrieved on the date 20.11.2016. from: http://www.econ.cam.ac.uk/people/ emeritus/mhp1/jasaold.pdf.

Pesaran, M. Hashem, and Yongcheol Shin (1999) "An Autoregressive Distributed Lag Modelling Approach to Cointegration Analysis", Econometric and Economic Theory in the 20th Century: The Ragnar Frish Centennial Symposium, pp. 371-413, http://dx.doi.org/10.1017/CCOL0521633230.011.

Ranicare, R. \& Laoyza, N. (2005) "Financial Development, Financial Fragility, and Growth", IMF Working paper WP/05/170. Retrieved on the date 10.05.2019. from https://www.imf.org/en/Publications/WP/Issues/2016/12/31/FinancialDevelopment-Financial-Fragility-and-Growth-18442.

Republic of Albania (2019) "Economic reform programme 2019-2021", Retrieved on the date 13.12.2019 from: https://ec.europa.eu/neighbourhoodenlargement/ sites/near/files/albania_erp_2019-2021.pdf.

Pesaran, M. Hashem, Yongcheol Shin, and Ron P. Smith (1997) "Pooled Estimation of Long-Run Relationships in Dynamic Heterogenous Panels", Retrieved on the date 20.11.2016 from: http://www.econ.cam.ac.uk/people/emeritus/mhp1/ jasaold.pdf.

Pesaran, M. Hashem, and Yongcheol Shin. (1999) "An Autoregressive Distributed Lag Modelling Approach to Cointegration Analysis Econometric and Economic Theory in the 20th Century", The Ragnar Frish Centennial Symposium, pp. 371-413, http://dx.doi.org/10.1017/CCOL0521633230.011.

Ranicare, R., Laoyza, N. (2005) "Financial Development, Financial Fragility, and Growth", IMF Working paper WP/05/170. Retrieved on the date 10.05.2019 from: https://www.imf.org/en/Publications/WP/Issues/2016/12/31/FinancialDevelopment-Financial-Fragility-and-Growth-18442.

World Bank (2019) "World Development Indicators", Retrieved on the date 10.05.2019 from: http://data.worldbank.org/data-catalog/world-developmentindicators. 


\title{
Učinci fiskalne konsolidacije u zemljama Zapadnog Balkana
}

\author{
Milenko Krajišnik ${ }^{1}$, Dragan Gligorić ${ }^{2}$, Biljana Gojković ${ }^{3}$
}

\begin{abstract}
Sažetak
Svjetska ekonomska kriza zahvatila je zemlje Zapadnog Balkana. Recesija koju je karakteriziralo smanjenje privredne aktivnosti, pad potrošnje $i$ povećanje zaposlenosti bila je praćena smanjenjem javnih prihoda. Posljedica takvog stanja je budžetska neravnoteža koja se manifestirala u vidu strukturnog budžetskog deficita $i$ rasta javnog duga. Fiskalna konsolidacija u svim zemljama bila je neophodna. U procesu fiskalne konsolidacije dolazi do promjene pojedinih elemenata fiskalne politike koji se razlikuju od zemlje do zemlje. U tom procesu, struktura javnih prihoda i javnih rashoda se mijenja. Postavlja se pitanje koliko je fiskalna konsolidacija bila uspješna i u kojoj mjeri. Dinamička panel analiza pomoću PMG procjenitelja u šest zemalja Zapadnog Balkana, za period od 20042016. godine pokazala je da fiskalna konsolidacija ima pozitivan utjecaj na ekonomski rast. Dakle, zemlje Zapadnog Balkana moraju voditi odgovorne financije kako bi potakle ekonomski rast.
\end{abstract}

Ključne riječi: BDP, budžetski deficit, javni dug, fiskalna konsolidacija

JEL klasifikacija: E62, H62, F41

${ }_{1}$ Izvanredni profesor, Univerzitet u Banjaluci, Ekonomski fakultet, Majke Jugovića 4, 7800 Banja Luka, Bosna i Hercegovina. Znanstveni interes: međunarodna ekonomija. Tel.: 0038765546019.E-mail:milenko.krajisnik@ef.unibl.org.

2 Docent, Univerzitet u Banjaluci, Ekonomski fakultet, Majke Jugovića 4, 7800 Banja Luka, Bosna i Hercegovina. Znanstveni interes: međunarodna ekonomija. Tel.: 0038765443355. E-mail:dragan.gligoric@ef.unibl.org.

${ }^{3}$ Magistar ekonomskih nauka, Načelnik odjeljenja za ekonomsku politiku i javne financije, Fiskalni savjet Republike Srpske, Trg Republike 8/XIII Banja Luka. Tel.: 0038765988335. E-mail: biljana.gojkovic@fiskalnisavjetrs.net. 


\section{Appendix}

Appendix No. 1: Success and effectiveness of fiscal consolidation in Western Balkans Countries

\begin{tabular}{|c|c|c|c|c|c|c|c|c|}
\hline Country & Description & 2004 & 2005 & 2006 & 2007 & 2008 & 2009 & 2010 \\
\hline \multirow{3}{*}{ Albanija } & GDP percentage change & 5,52 & 5,53 & 5,90 & 5,98 & 7,50 & 3,35 & 3,71 \\
\hline & $\begin{array}{l}\text { Cyclically-adjusted } \\
\text { primary balance, } \% \text { of } \\
\text { potential GDP }\end{array}$ & $(0,90)$ & 0,20 & $(0,20)$ & $(0,80)$ & $(3,50)$ & $(4,50)$ & $(0,40)$ \\
\hline & Public debt ( $\%$ of GDP) & 57,47 & 58,20 & 56,69 & 53,55 & 55,14 & 59,67 & 57,72 \\
\hline \multirow{3}{*}{$\begin{array}{l}\text { Bosnia and } \\
\text { Herzegovina }\end{array}$} & GDP percentage change & 6,26 & 4,24 & 5,69 & 5,98 & 5,59 & $(0,82)$ & 0,77 \\
\hline & $\begin{array}{l}\text { Cyclically-adjusted } \\
\text { primary balance, \% of } \\
\text { potential GDP } \\
\end{array}$ & 1,03 & 2,16 & 2,95 & $(0,22)$ & $(5,80)$ & $(5,59)$ & $(3,60)$ \\
\hline & Public debt ( $\%$ of GDP) & 25,49 & 25,52 & 21,25 & 18,71 & 30,89 & 35,07 & 40,81 \\
\hline \multirow{3}{*}{ Croatia } & GDP percentage change & 3,92 & 4,11 & 4,87 & 5,28 & 2,04 & $(7,29)$ & $(1,47)$ \\
\hline & $\begin{array}{l}\text { Cyclically-adjusted } \\
\text { primary balance, } \% \text { of } \\
\text { potential GDP }\end{array}$ & $(3,75)$ & $(2,89)$ & $(3,25)$ & $(3,36)$ & $(3,52)$ & $(3,47)$ & $(2,12)$ \\
\hline & Public debt (\% of GDP) & 40,28 & 41,17 & 38,65 & 37,26 & 39,00 & 48,30 & 57,35 \\
\hline \multirow{3}{*}{ Montenego } & GDP percentage change & 4,40 & 4,20 & 8,60 & 6,80 & 7,20 & $(5,80)$ & 2,70 \\
\hline & $\begin{array}{l}\text { Cyclically-adjusted } \\
\text { primary balance, } \% \text { of } \\
\text { potential GDP }\end{array}$ & & & & 8,64 & $(1,43)$ & $(3,25)$ & $(2,30)$ \\
\hline & Public debt ( $\%$ of GDP) & 45,37 & 38,57 & 36,69 & 31,76 & 34,19 & 43,69 & 45,01 \\
\hline \multirow{3}{*}{$\begin{array}{l}\text { North } \\
\text { Macedonia }\end{array}$} & GDP percentage change & 4,67 & 4,72 & 5,14 & 6,47 & 5,47 & $(0,36)$ & 3,36 \\
\hline & $\begin{array}{l}\text { Cyclically-adjusted } \\
\text { primary balance, } \% \text { of } \\
\text { potential GDP }\end{array}$ & 1,21 & 1,04 & 0,41 & 1,32 & $(0,34)$ & $(2,09)$ & $(1,74)$ \\
\hline & Public debt (\% of GDP) & 34,58 & 36,67 & 30,59 & 23,53 & 20,64 & 23,57 & 24,06 \\
\hline \multirow{3}{*}{ Serbia } & GDP percentage change & 9,05 & 10,15 & 5,11 & 6,44 & 5,66 & $(2,73)$ & 0,73 \\
\hline & $\begin{array}{l}\text { Cyclically-adjusted } \\
\text { primary balance, } \% \text { of } \\
\text { potential GDP }\end{array}$ & & 2,90 & $(0,38)$ & $(1,49)$ & $(3,52)$ & $(3,13)$ & $(2,94)$ \\
\hline & Public debt ( $\%$ of GDP) & 62,18 & 51,31 & 37,97 & 31,20 & 30,56 & 33,93 & 41,22 \\
\hline
\end{tabular}


Milenko Krajišnik et al. • Effects of fiscal consolidationin Western Balkan Countries

\begin{tabular}{|c|c|c|c|c|c|c|c|c|c|}
\hline Country & Description & 2011 & 2012 & 2013 & 2014 & 2015 & 2016 & 2017 & 2018 \\
\hline \multirow{3}{*}{ Albanija } & $\begin{array}{l}\text { GDP percentage } \\
\text { change }\end{array}$ & 2,55 & 1,42 & 1,00 & 1,77 & 2,22 & 3,32 & 3,82 & 4,06 \\
\hline & $\begin{array}{l}\text { Cyclically-adjusted } \\
\text { primary balance, } \% \text { of } \\
\text { potential GDP }\end{array}$ & $(0,90)$ & $(0,50)$ & $(1,50)$ & $(1,80)$ & $(0,70)$ & 1,20 & 0,40 & 0,50 \\
\hline & $\begin{array}{l}\text { Public debt (\% of } \\
\text { GDP) }\end{array}$ & 59,41 & 62,14 & 70,39 & 71,99 & 73,72 & 73,32 & 71,87 & 69,92 \\
\hline \multirow{3}{*}{$\begin{array}{l}\text { Bosnia and } \\
\text { Herzegovina }\end{array}$} & $\begin{array}{l}\text { GDP percentage } \\
\text { change }\end{array}$ & 0,91 & $(0,71)$ & 2,35 & 1,15 & 3,07 & 3,22 & 3,11 & 3,62 \\
\hline & $\begin{array}{l}\text { Cyclically-adjusted } \\
\text { primary balance, } \% \text { of } \\
\text { potential GDP }\end{array}$ & $(1,80)$ & $(0,53)$ & 0,16 & $(0,56)$ & 1,67 & 1,82 & 2,94 & 2,36 \\
\hline & $\begin{array}{l}\text { Public debt (\% of } \\
\text { GDP) }\end{array}$ & 39,55 & 42,21 & 42,50 & 45,86 & 45,53 & 44,08 & 39,24 & 34,25 \\
\hline \multirow{3}{*}{ Croatia } & $\begin{array}{l}\text { GDP percentage } \\
\text { change }\end{array}$ & $(0,34)$ & $(2,30)$ & $(0,49)$ & $(0,09)$ & 2,40 & 3,54 & 2,92 & 2,63 \\
\hline & $\begin{array}{l}\text { Cyclically-adjusted } \\
\text { primary balance, } \% \text { of } \\
\text { potential GDP }\end{array}$ & $(1,90)$ & $(0,56)$ & $(0,26)$ & 0,31 & 1,36 & 2,30 & 3,10 & 3,07 \\
\hline & $\begin{array}{l}\text { Public debt (\% of } \\
\text { GDP) }\end{array}$ & 63,87 & 69,49 & 80,40 & 83,99 & 83,73 & 80,48 & 77,76 & 74,57 \\
\hline \multirow{3}{*}{ Montenego } & $\begin{array}{l}\text { GDP percentage } \\
\text { change }\end{array}$ & 3,20 & $(2,72)$ & 3,55 & 1,78 & 3,39 & 2,95 & 4,72 & 4,90 \\
\hline & $\begin{array}{l}\text { Cyclically-adjusted } \\
\text { primary balance, } \% \text { of } \\
\text { potential GDP }\end{array}$ & $(4,14)$ & $(2,12)$ & $(1,78)$ & 0,07 & $(5,84)$ & $(1,64)$ & $(3,62)$ & $(1,62)$ \\
\hline & $\begin{array}{l}\text { Public debt (\% of } \\
\text { GDP) }\end{array}$ & 48,57 & 56,87 & 58,65 & 63,36 & 68,95 & 66,58 & 66,30 & 72,57 \\
\hline \multirow{3}{*}{$\begin{array}{l}\text { North } \\
\text { Macedonia }\end{array}$} & $\begin{array}{l}\text { GDP percentage } \\
\text { change }\end{array}$ & 2,34 & $(0,46)$ & 2,93 & 3,63 & 3,86 & 2,85 & 0,24 & 2,67 \\
\hline & $\begin{array}{l}\text { Cyclically-adjusted } \\
\text { primary balance, } \% \text { of } \\
\text { potential GDP }\end{array}$ & $(1,77)$ & $(2,93)$ & $(2,95)$ & $(3,25)$ & $(2,34)$ & $(1,56)$ & $(0,60)$ & $(0,90)$ \\
\hline & $\begin{array}{l}\text { Public debt (\% of } \\
\text { GDP) }\end{array}$ & 27,73 & 33,66 & 33,97 & 38,02 & 38,05 & 39,81 & 39,48 & 40,47 \\
\hline \multirow{3}{*}{ Serbia } & $\begin{array}{l}\text { GDP percentage } \\
\text { change }\end{array}$ & 2,04 & $(0,68)$ & 2,89 & $(1,59)$ & 1,78 & 3,34 & 2,05 & 4,30 \\
\hline & $\begin{array}{l}\text { Cyclically-adjusted } \\
\text { primary balance, } \% \text { of } \\
\text { potential GDP }\end{array}$ & $(3,44)$ & $(3,70)$ & $(2,94)$ & $(2,22)$ & 0,01 & 1,71 & 3,48 & 2,85 \\
\hline & $\begin{array}{l}\text { Public debt (\% of } \\
\text { GDP) }\end{array}$ & 43,97 & 54,44 & 57,51 & 67,59 & 71,28 & 68,88 & 58,73 & 54,55 \\
\hline
\end{tabular}

Source: IMF, World Economic Outlook Databases, Economic reform programme 2019-2022 (Republic of Albania, Macedonia, North Montenegro) and Authors' calculation 